\title{
The House of Representatives' Role in Guarding Government Policies to Resolve the Covid-19 Pandemic According to the 1945 Constitution
}

\author{
Bayu Dwi Anggono ${ }^{1}$, Fahmi Ramadhan Firdaus ${ }^{2}$ \\ ${ }^{1}$ Faculty of Law, Universias Jember, Indonesia, \\ E-mail:bayu_fhunej@yahoo.co.id \\ ${ }^{2}$ Faculty of Law, Universitas Indonesia, Indonesia, \\ E-mail:fhmiramadhan@gmail.com
}

Submitted: January 5, 2021; Reviewed: May 31, 2021; Accepted: June 2, 2021

\begin{tabular}{ll}
\hline \multicolumn{1}{c}{ Article Info } & \multicolumn{1}{c}{ Abstract } \\
\hline $\begin{array}{l}\text { Keywords: } \\
\text { House of } \quad \text { Representative, } \\
\text { Government, Covid-19, Monitoring. }\end{array}$ & $\begin{array}{l}\text { The responsibility to handle the Covid-19 Pandemic } \\
\text { is nonly carried out by the President as the highest } \\
\text { leader of the government, but also the House of } \\
\text { Representatives which holds the legislative branch } \\
\text { of power, so far the public has questioned the } \\
\text { 10.25041/fiatjustisia.v15vno4.2314 } \\
\text { seriousness of Parliament in handle the Pandemic, } \\
\text { through its functions should be able to assist and } \\
\text { especially to monitoring policy government to work } \\
\text { together to handle this pandemic and as an effort to } \\
\text { prevent potential abuse of power. The writing of this } \\
\text { article uses the Juridical Normative method which } \\
\text { will produce recommendations on how the House of } \\
\text { Representatives should optimize its function during } \\
\text { the Covid-19 Pandemic. }\end{array}$ \\
\hline
\end{tabular}

\section{A. Introduction}

At the end of 2019, the world was shocked by the Covid-19 virus which was thought to have originated from Wuhan, China. This virus then quickly infected nearly 250 countries in the world, one of which is Indonesia, the rapid and massive spread of the virus forced the World Health Organization (WHO) to set the Covid-19 outbreak to become a Global Pandemic ${ }^{1}$

As we know, the Covid-19 cases in Indonesia were known in early March 2020. Until now, the number of confirmed cases of Covid-19 has reached

1 WHO, "WHO Timeline - COVID-19," Who.int, accessed April 27, 2020, https://www.who.int/news-room/detail/27-04-2020-who-timeline---covid-19. 
above 350,000 and is increasing every day by an average of 3,000-4,000 cases. Not only does it affect the health aspect, but the COVID-19 also causes considerable material losses. Various aspects were affected, both the socioculture and the weakening world economy. ${ }^{2}$

The government does not remain silent as the most responsible organ for overcoming the outbreak, as in Article 10 of Law No. 4 of 1984 on Communicable Disease Outbreaks, it is stated that the Government is responsible for implementing epidemic prevention efforts. This situation cannot be tolerated because it will cause a prolonged crisis, in the context of handling it as a rule of $\operatorname{law}^{3}$, a legal instrument is needed in the form of statutory regulations.

The President has issued various laws and policy regulations, including Presidential Decree Number 7 of 2020 concerning the Task Force for the Acceleration of Handling COVID-19, Government Regulation Number 21 of 2020 concerning Large-Scale Social Restrictions (PSBB) in the Framework of Accelerating Handling of COVID-19, Presidential Decree 11/2020 concerning Determination of Public Health Emergency Status, Perppu No. 1 of 2020 concerning State Financial Policy and Financial System Stability for Handling the COVID-19 Pandemic which was ratified as Law No. 2 of 2020, Presidential Decree Number 54 of 2020 concerning Posture Changes and Details of the State Budget for the 2020 Fiscal Year, Presidential Decree Number 12 of 2020 concerning the Determination of Non-Natural Disasters for the Spread of COVID-19 as National Disasters, Presidential Regulation Number 82 of 2020 concerning the Covid-19 Management Committee and National Economic Recovery, and Presidential Instruction No. 6 of 2020 concerning Increasing Discipline and Law Enforcement of Health Protocols in the Prevention and Control of Corona Virus Disease 2019.

The response to the Covid-19 pandemic is certainly not the sole responsibility of the government as a branch of executive power. Various laws and regulations and policy regulations in dealing with Covid-19 have implications for wide discretionary powers of government and finance, for example in Law No. 2 of 2020 which regulates the fields of state fiscal policy, taxation, and financial and business system stability policies. This law stipulates a budget for handling COVID-19 of Rp. 405.1 trillion. The details, amounting to Rp. 75 trillion for the health sector, Rp. 110 trillion for the social

\footnotetext{
${ }^{2}$ Fahmi Ramadhan Firdaus and Anna Erliyana Chandra, "Perlindungan Kebijakan Diskresi Dalam Penanganan Covid-19 Menurut Undang-Undang No. 2 Tahun 2020," Jurnal Pakuan Law Review 6, no. 2 (2020): 24-41, https://doi.org/10.33751/palar.v6i2.2128.

${ }^{3}$ Article 1 Section (3) Indonesia Constitution 1945 348
} 
safety net. Then Rp. 70.1 trillion for tax incentives and stimulus for People's Business Credit (KUR). As well as Rp. 150 trillion allocated to finance the national economic recovery program. This is of course prone to abuse, as Lord Acton said, "Power tends to corrupts, absolute power corrupts absolutely". ${ }^{4}$

According to Rajendran, a researcher from Mumbai University, the potential for diversion of disaster funds is more wide open and often occurs in Asian countries, especially in developing countries. Because the government and the public only focus on handling, prevention, and post-disaster recovery. However, there is minimal monitoring of the use of funds, especially since it is not certain that procedures are followed to ensure that the funds are efficient and right on target. ${ }^{5}$

To avoid abuse of authority and finance in dealing with Covid-19, supervision must be strengthened. Informally, supervision can be carried out by the public, public involvement in both policymaking and policy implementation is a picture of a democratic rule of law. ${ }^{6}$ Public participation efforts are a preventive way so that state officials are right in making policies and managing budgets for handling Covid-19.

Apart from informal supervision, formal supervision by institutions is no less important. The House of Representatives (DPR) as a branch of legislative power through its functions, namely legislation, budgeting, and especially supervision, plays a very important role in implementing the Checks and Balances System principles so that the performance of the government as a branch of legislative power runs on the track according to the 1945 Constitution and statutory regulations that applies in all situations, including this Pandemic.

However, instead of focusing on the supervisory function, the House of Representatives during the Pandemic received a lot of sharp criticism because it discussed laws that were not relevant to the interests of the community and the handlers of Covid-19, discussions in the middle of the pandemic had an impact on limited public participation, for example, the discussion of the Work Creation Bill just passed in the plenary meeting October 5, 2020.

The current health emergency should make Parliament focus on providing great oversight to the government so that handling of the pandemic can be

\footnotetext{
4 Acton Institute, "Lord Acton Quote Archive," Acton.org, n.d., https://www.acton.org/research/lord-acton-quote-archive.

5 Kontan, "Mengawal Perppu Covid-19," Kontan. co.id, n.d., https://analisis.kontan.co.id/news/mengawal-perppu-covid-19.

${ }^{6}$ Saut P. Panjaitan, "Jaminan Perlindungan Konstitusional Hak Tiap Orang Untuk Memperoleh Informasi Dan Berkomunikasi,” Jurnal Simbur Cahaya 15, no. 42 (2010): 1957-58.
} 
right on target and minimize abuse of power. Because when the government focuses on dealing with the pandemic, the protection of citizens from the threat of Covid-19 can be maximized.

Many things need to be supervised by the Parliament in implementing the policy for handling Covid-19, this is solely to guarantee the health rights of citizens guaranteed by the 1945 Constitution, based on Law Number 36 of 2009 concerning Health as mentioned in Article 5 Paragraph (1) people have the same right to gain access to resources in the health sector. (2) Everyone has the right to obtain safe, quality, and affordable health services. (3) Everyone has the right to independently and responsibly determine the necessary health services for himself. Thus, health is a right for all people regardless of ethnicity, culture, religion, or economic strata, and the government, as well as local governments and communities, are responsible for the implementation of these health efforts as stated in Article 49 paragraph (1) Law Number 36 of 2009

Supervision is very important because in the field there is still the fulfilment of the rights to health which is not evenly and maximally, especially for health workers who in various hospitals still lack Personal Protective Equipment (PPE) ${ }^{7}$, whereas this is the responsibility of the government based on Article 26 paragraph (2) and Article 13 of Law Number 36 the Year 2014 concerning Health Workers.

Article 26 paragraph (2) stated "Head of Health Service Facilities as referred to in paragraph (1) and / or regional heads in charge of health service facilities must consider meeting the needs for clothing, food, shelter, and location, as well as work safety and security for health workers. With the provisions of the Legislation.

Article 13 stated, "The Government and Local Governments are required to meet the needs of Health Workers, both in number, type and competency equally to ensure the sustainability of health development."

The above events should not have happened because doctors, nurses, and other medical personnel are at the forefront of fighting Covid-19. Lack of APB can increase the risk of medical personnel contracting Covid-19, and this is undesirable because it can make the pandemic situation worse.

\footnotetext{
7 Republika, “APD Yang Terus Menerus Kurang,” Republika. co.id, n.d., https://republika.co.id/berita/q83350328/apd-yang-terus-menerus-kurang. 350
} 
The full responsibility now lies with the state, in this case, the government and the DPR, to work together to protect their citizens, as Cicero said: "Salus populi suprema lex esto", which means that people's safety is the highest law. ${ }^{8}$

This article will explain how the DPR functions and its relation to overcoming Covid-19 with the Government according to the 1945 Constitution, the concept of supervision, and the form of supervision that can be carried out by DPR.

The research method used is juridical normative and with a conceptual approach based on how the concept of supervision and how the DPR should carry out its supervisory function towards the government in tackling the Covid-19 Pandemic. Besides, this article uses a statutory approach by analyzing the products of the laws and regulations issued during the Covid-19 Pandemic.

\section{B. Discussion}

\section{The Function of the House of Representatives and Its Relevance in the Response to Covid-19}

The Trias Politica theory put forward by Montesquieu divides state power into 3 (three) powers, namely (1) legislative power or the power to make laws (rulemaking function); (2) executive power or power to implement laws (rule application function); (3) judicial power or the power to judge violations of the law (rule adjudication function).

In general, there are three main functions carried out by legislative institutions in the world, namely the representative function, the legislative function, and the supervisory function. First, the function of representation refers to the function of parliament in representing the sovereignty of the people. Therefore, they have a moral obligation to represent and fight for the interests and opinions of all segments of society, not only those groups of people who have elected them in elections. Second, the legislative function is the oldest or most traditional function of the parliamentary institution. This function refers to the making or deliberation of general rules that bind all citizens. Third, the capacity to control potential deviations from executive

\footnotetext{
8 Goodreads, "Cicero Quotes," Goodreads.com, n.d., https://www.goodreads.com/quotes/531811-salus-populi-suprema-est-lex-the-good-of-thepeople.
} 
power and initiative is another fundamental task that parliaments should have. ${ }^{9}$

In Indonesia, the legislative branch of power is held by the DPR and is included in the category of playing organs. The position of the DPR is regulated in the Constitution, namely Articles 19 to 22B of the 1945 Constitution. Based on Article 20A, apart from having a legislative function as the main power, the House of Representatives also has a budget function and a supervisory function.

The function of the House of Representatives as mandated by the 1945 Constitution of the Republic of Indonesia is further regulated in Law No. 17 of 2014 concerning the MPR, DPR, and DPRD as last amended by Law no. 2 of 2018 concerning the MPR, DPR, and DPRD in Part Two in Article 69 paragraph (1) and (2) and Article 70 paragraph (1), (2) and (3). ${ }^{10}$ Based on Article 69 paragraph (1), the DPR has functions, namely legislation, budgeting, and supervision. (2) It is explained in paragraph (2) that the three functions of legislation, supervision and budgeting as referred to in paragraph (1) are carried out within the framework of people's representation, and also to support the Government's efforts in implementing foreign policy following the provisions of laws and regulations.

The meaning of these functions is explained in Article 70. Paragraph (1) regulates the legislative function, as referred to in Article 69 paragraph (1) letter a, which is implemented as the manifestation of the DPR as the holder of the power to form laws. Then paragraph (2) describes the function of the budget in which Article 69 paragraph (1) letter b is implemented to discuss and give approval or not to approve the bill on the State Budget submitted by the President. Finally, paragraph (2) regulates the supervisory function, as referred to in Article 69 paragraph (1) letter c, which is carried out through supervision of the implementation of laws and the State Budget.

During the Covid-19 Pandemic situation, the DPR has carried out its function, about handling Covid-19 the legislative function of the DPR has passed Perppu No. 1 of 2020 concerning State Financial Policies and Financial System Stability for Handling the COVID-19 Pandemic into Law No. 2 of 2020 .

\footnotetext{
${ }^{9}$ Wawan Ichwanudin, “Absennya Politik Pengawasan DPR Era Reformasi,” Jurnal Penelitian Politik 9, no. 2 (2010): 91-104, https://doi.org/https://doi.org/10.14203/jpp.v9i2.233.

${ }^{10}$ Article 69 section (1) and (2) and Article 70 section (1), (2) and (3) Law No. 17 of 2014 on the MPR, DPR, and DPRD last time amendment with Law No. 2 of 2018 on the MPR, DPR dan DPRD (State Gazette of 2018 Number 29, State Gazette Number 6187) 352
} 
In addition, to carry out the Local Election Simultaneously amid the Pandemic, the House of Representatives has passed Perppu No. 2 of 2020 concerning the Third Amendment to Law No. 1 of 2015 concerning Stipulation of Perppu No. 1 of 2014 concerning the Election of Governors, Regents and Mayors into Law No. 6 of 2020, this law has implications for changing the schedule for each stage of the Pilkada Simultaneously, which initially held the election on 23 September 2020, changed to 9 December 2020, then the implementation of the Simultaneous Pilkada in 2020 must also be implemented with strict Health Protocols to minimize the occurrence of Local Election clusters.

Regarding the budget function, the DPR has monitoring and provided input on the ABPN Amendment for handling Covid-19. ${ }^{11}$ Previously, the Government had submitted an amendment to the 2020 State Budget (APBN) to the DPR. The APBN design was changed because it adjusted to the handling of the Covid-19 pandemic in Indonesia, which had not yet subsided.

It is necessary to note that changes in the posture of the APBN are carried out through Government Regulation in lieu of Law number 1 of 2020 which is later stipulated as Law number 2 of 2020 which regulates that changes in the posture of the APBN can be made through a Presidential Regulation.

The first amendment is through Presidential Regulation number 54 of 2020 concerning Posture Changes and Details of the State Revenue and Expenditure Budget for the 2020 Fiscal Year which causes revenue to fall from Rp. 2,233.2 trillion to Rp. 1,760.0 trillion. State expenditures increased from Rp. 2,540.4 trillion to Rp. 2,613.8 trillion. This change in the design of the 2020 State Budget also has consequences on the widening of the APBN deficit which was originally in the range of Rp. 307.2 trillion or 1.76 percent to Rp. 853 trillion or around $5.07 \% .^{12}$

The second amendment was made through Presidential Regulation No. 72 of 2020 on 24 June 2020. The government has rearranged the spending posture due to Covid-19 as a revision of Presidential Regulation number 54 of 2020 issued in early April. The contents of this Presidential Decree outline that state revenue is revised down by Rp. 60.93 trillion from Rp. 1,760.88 trillion to Rp. $1,699.95$ trillion. The decline in the state revenue target was mainly driven by

\footnotetext{
${ }^{11}$ DPR, “DPR Terus Kawal Belanja Negara Untuk Penanganan Covid-19," Dpr.go.id, n.d., dpr.go.id/berita/detail/id/28713/t/DPR+Terus+Kawal+Belanja+Negara+Untuk+Penanganan+ Covid-19.

${ }^{12}$ Merdeka, "Pemerintah Jokowi Resmi Ajukan Perubahan Susunan Anggaran Di APBN 2020 Ke DPR," Merdeka.com, n.d., https://www.merdeka.com/uang/pemerintah-jokowi-resmiajukan-perubahan-susunan-anggaran-di-apbn-2020-ke-dpr.html.
} 
the tax revenue target which fell from $\mathrm{Rp} 1,462.63$ trillion to $\mathrm{Rp} 1,404.51$ trillion. Non-tax state revenues also decreased from Rp 297.75 trillion to $\mathrm{Rp}$ 294.14 trillion, while grant revenues increased from $\mathrm{Rp} 498.74$ billion to $\mathrm{Rp}$ 1 trillion. However, state spending increased by Rp 125.34 trillion from Rp 2,613.82 trillion to $\mathrm{Rp} 2,739.16$ trillion. The central government budget is set at Rp. 1,851.1 trillion, including additional spending on handling the Corona Pandemic of Rp. 255.11 trillion. The budget for transfers to the regions is set at Rp. 763.92 trillion, including additional expenditure for handling Covid-19 of Rp. 5 trillion, with the revised revenue and expenditure, the budget deficit or financing in Presidential Decree Number 72 of 2020 is set at Rp. 1,039 trillion or $6.37 \%$ of GDP. This financing consists of debt financing, investment, loan provision, loan obligations, and other financings. ${ }^{13}$

Regarding the supervisory function that should be carried out by the House of Representatives regarding government policies in handle the Covid-19 Pandemic so that it is under the applicable laws and regulations, it will be discussed in the next sub-chapter.

\section{Supervision Concept}

Supervision is needed in a state organization, especially if Indonesia is a country with the type of the Unitary State (Welfare State). The type of state of the Welfare State itself must carry out public welfare and services of interest. ${ }^{14}$

Supervision is generally defined as an administrative activity that aims to rely on the evaluation of the work that has been completed whether it is according to plan or not. Because it is not intended to find out who is the right one, but rather to make corrections to the results of the activity. Thus, if some errors or deviations are not under the target to be achieved, steps are immediately taken to straighten out the next activity so that its implementation is directed. To achieve an optimal supervisory system, a structured and integrated approach must be established starting from the planning, implementation, reporting, and follow-up of the results of supervision by all interested parties and work units. Supervision of governance is a process of

\footnotetext{
${ }^{13}$ Katadata, "Jokowi Teken Perpres Revisi Kedua APBN 2020, Deficit Angaran RP 1039 T," Katadata.co.id, n.d., https://katadata.co.id/agustiyanti/finansial/5ef592357d095/jokowi-tekenpepres-revisi-kedua-apbn-2020-defisit-anggaran-rp1039-t.

${ }_{14}$ Angger Sigit Pramukti and Meylani Chayaningsih, Pengawasan Hukum Terhadap Aparatur Negara (Yogyakarta: Pustaka Yustisia, 2016). 354
} 
activities aimed at ensuring that the government conforms to the plans and provisions of the prevailing laws and regulations. ${ }^{15}$

According to Prayudi, supervision is a series of efforts in deciding which activities have been carried out and carried out with what is desired, planned, or considered. ${ }^{16}$ Meanwhile, Saiful Anwar stated that activities and tasks carried out by government officials or agencies need to be monitored so that the activities and tasks carried out do not deviate and the desired objectives can be achieved. ${ }^{17}$

Goerge R. Terry defines supervision as "control is to determine what is completed evaluate it, and apply a corrective measure, if needed to insure result in keeping with plan." That is, supervision is carried out to provide evaluation and make corrections to the results achieved and compared with what was previously planned. ${ }^{18}$

In obtaining the desired goals and preventing deviant and deviant actions, supervision is needed. This means that by carrying out this supervision, the possibility of carrying out an activity following the applicable regulations is getting bigger, and the desired objectives can be realized. Supervision can function as a detector and assessor of abuse committed in the implementation of activities. ${ }^{19}$

The type of supervision is then divided into 2 (two) namely internal supervision and external supervision. According to Mulyadi, internal supervision includes organizational structure, methods, and measures that are coordinated to maintain organizational wealth, check the accuracy and reliability of accounting data, promote efficiency and encourage compliance with management policies. ${ }^{20}$

Meanwhile, external supervision is a supervisory action carried out by an agency within an organizational structure that is outside the government structure. For example, financial supervision measures are carried out by the

\footnotetext{
${ }^{15}$ Lembaga Adiministrasi Negara, Modul Pendidikan Dan Pelatihan Kepemimpinan Tingkat IV, Sistem Administrasi Negara Republik Indonesia (SANRI) (Jakarta: Lan RI, 2008).

${ }^{16}$ Amran Suadi, Sistem Pengawasan Badan Peradilan Di Indonesia (Depok: Rajawali Press, 2014).

17 Saiful Anwar, Sendi-Sendi Hukum Administrasi Negara (Medan: Gelora Madani Press, 2004).

18 Irfan Fachruddin, Pengawasan Peradilan Administrasi Terhadap Tindakan Pemerintah (Bandung: Alumni, 2004).

${ }^{19}$ Suadi, Sistem Pengawasan Badan Peradilan Di Indonesia.

${ }^{20}$ Mulyadi, Pemeriksaan Dalam Pengawasan (Bandung: Remaja Rosdakarya, 1984).
} 
Supreme Audit Agency (BPK) and supervision of the code of ethics and behaviour of judges by the Judicial Commission. ${ }^{21}$

In addition, there is a concept of legislative control, which is better known as political supervision, which is the supervision carried out by the DPR towards the government under its duties, powers, and rights. ${ }^{22}$ This is a form of the implementation of the checks and balances system between the legislative and executive branches of power.

Of course, as a democratic country, the community has a role in monitoring. Supervision by the community is a form of community participation in governance. Supervision by the community can be carried out individually, representatives of groups of service users, representatives of observer groups, or representatives of legal entities that have concerns about the administration of Government.

Public participation in the state administration is a fundamental right that is guaranteed constitutionally, this right is a manifestation of the people's sovereignty by the mandate of Article 1 paragraph (2) of the 1945 Constitution of the Republic of Indonesia. To provide space for the public in state administration.

Situmorang stated that the purpose of supervision is to create an ideal government apparatus with the correct system and governance, besides that it is supported by community members who participate in carrying out supervision over the implementation of a government administration. ${ }^{23}$

\section{Forms of Supervision of Government Policies in Handling Covid-19}

The function of the representative body does not stop at the formation of laws only but also ensures how the implementation of the law is per the purpose for which it was formed. According to Jimly Asshidiqie, the supervisory function is more important than the legislative function itself. The supervisory function is not only concerned with the performance of the government in implementing statutory provisions or predetermined policies, but also with the determination of the stipulated budget and implementation

\footnotetext{
${ }^{21}$ Suadi, Sistem Pengawasan Badan Peradilan Di Indonesia.

${ }^{22}$ Nur Cholis, Teori Dan Praktek Pemerintahan Dan Otonomi Daerah (Jakarta: Grasindo, 2005).

${ }^{23}$ M. Situmorang, Viktor, and Jusuf Juhir, Aspek Hukum Pengawasan Melekat Dalam Lingkungan Aparatur Pemerintah (Jakarta: Rineka Cipta, 1994). 356
} 
of the APBN. Thus, the supervisory function also reflects the budget function, namely fiscal supervision. ${ }^{24}$

What Jimly Asshidiqie expressed has been done by the House of Representatives in the context of monitoring budget determination through Presidential Decree Number 54 of 2020 and Presidential Decree Number 72 of 2020, which changes the posture of the 2020 budget.

But unfortunately, we have not yet seen the maximum oversight function of the DPR in the context of implementing the APBN that has been determined for handling Covid-19. We can see various problems on the ground that need further supervision by the DPR. First, regarding the uneven fulfillment of PPE, in addressing this problem the DPR can play a role in urging the government to provide incentives for companies that produce PPE, so that production can be fast and at an affordable price.

Second, the implementation of large-scale social restrictions (PSBB) in Jakarta and several other areas, until now has been relatively unable to suppress the spread of Covid-19, the DPR should have urged the government to evaluate the implementation of PSBB in several areas.

Third, Social assistance or social safety nets and the like for the poor and vulnerable that have been budgeted for in the APBN are still not on target, this will have the potential to cause corruption. To avoid miss targeting, the DPR should be able to urge the government, in this case, the Ministry of Social Affairs to improve data on recipients of the social safety net.

Fourth, absorption of the ministry's budget that is not optimal, even by the Ministry of Health, which should be the core of Covid-19 countermeasures, absorption of budget allocations for the health sector is still low. The progress of the realization of the health budget has only reached Rp. 21.79 trillion or $24.9 \%$ of the budget ceiling of Rp. 87.55 trillion. ${ }^{25}$ Based on data from the Ministry of Finance as of August 25, 2020, the realization of the budget for handling Covid-19 that has been distributed has only reached Rp. 174.79 trillion or 25.1 percent of the ceiling set at Rp. 695.2 trillion. ${ }^{26}$ The Parliament

\footnotetext{
${ }^{24}$ Putu Eva Ditayani, "Implementasi Fungsi Pengawasan Dewan Perwakilan Rakyat Dalam Upaya Memperkuat Sistem Presidensial Di Indonesia," Jurnal Refleksi Hukum 4, no. 2 (2020): 217-38, https://doi.org/https://doi.org/10.24246/jrh.2020.v4.i2.p217-238.

${ }^{25}$ Detik, "Rendah, Serapan Anggaran COVID-19 Sektor Kesehatan Baru 25\%," Detik.com, n.d., https://finance.detik.com/berita-ekonomi-bisnis/d-5194847/rendah-serapan-anggarancovid-19-sektor-kesehatan-baru-25.

${ }^{26}$ Bisnis, "Penyerapan Anggaran Covid-19 Masih Rendah, Ini Catatan INDEF," Bisnis.com, n.d., https://ekonomi.bisnis.com/read/20200827/44/1283830/penyerapan-anggaran-covid-19masih-rendah-ini-catatan-indef.
} 
should insist that budget absorption be maximized because it will indirectly help the people's economy.

One more thing that should be supervised by the Parliament is the readiness of the election organizers and the government to carry out the Simultaneous Local Election on December 9, 2020, the implementation of health protocols must be strictly enforced at every stage so that this year's Local Election will not cause a new Covid-19 Cluster which will worsen Pandemic.

\section{Conclusion}

The Covid-19 pandemic has made many countries in the world experience a crisis, almost all countries are overwhelmed in overcoming it, including in Indonesia. Prevention of outbreaks is the responsibility of the government, but that does not mean that other state institutions do not have the responsibility to participate in dealing with it. The House of Representatives as a branch of legislative power that has legislative, budgeting, and supervisory functions plays an important role in guarding government policies so that the response to Covid-19 is maximized and following applicable laws and regulations.

In the context of dealing with the pandemic, DPR has played a role through its functions, including legislation, budgeting, and supervision. But as a priority, DPR should better focus on the supervisory function, this cannot be separated from the reality that occurs in the field related to the many problems faced by the government, including the uneven fulfilment of PPE, the distribution of social assistance, or social safety nets that are not right on target and absorption; the budget that is far from the target. In addition, oversight of the implementation of Law No.2 of 2020 needs to be the focus of the DPR because the budget issued from the birth of the law is large enough so that it is feared that it is prone to corruption.

\section{References}

Acton Institute. "Lord Acton Quote Archive." Acton.org, n.d. https://www.acton.org/research/lord-acton-quote-archive.

Anwar, Saiful. Sendi-Sendi Hukum Administrasi Negara. Medan: Gelora Madani Press, 2004.

Bisnis. "Penyerapan Anggaran Covid-19 Masih Rendah, Ini Catatan INDEF." Bisnis.com, n.d. https://ekonomi.bisnis.com/read/20200827/44/1283830/penyerapananggaran-covid-19-masih-rendah-ini-catatan-indef.

Cholis, Nur. Teori Dan Praktek Pemerintahan Dan Otonomi Daerah. Jakarta: 
Grasindo, 2005.

Detik. "Rendah, Serapan Anggaran COVID-19 Sektor Kesehatan Baru 25\%."

Detik.com, n.d. https://finance.detik.com/berita-ekonomi-bisnis/d-

5194847/rendah-serapan-anggaran-covid-19-sektor-kesehatan-baru-25.

Ditayani, Putu Eva. "Implementasi Fungsi Pengawasan Dewan Perwakilan

Rakyat Dalam Upaya Memperkuat Sistem Presidensial Di Indonesia."

Jurnal Refleksi Hukum 4, no. 2 (2020): 217-38.

https://doi.org/https://doi.org/10.24246/jrh.2020.v4.i2.p217-238.

DPR. "DPR Terus Kawal Belanja Negara Untuk Penanganan Covid-19."

Dpr.go.id,

n.d.

dpr.go.id/berita/detail/id/28713/t/DPR+Terus+Kawal+Belanja+Negara

+Untuk+Penanganan+Covid-19.

Fachruddin, Irfan. Pengawasan Peradilan Administrasi Terhadap Tindakan

Pemerintah. Bandung: Alumni, 2004.

Firdaus, Fahmi Ramadhan, and Anna Erliyana Chandra. "Perlindungan

Kebijakan Diskresi Dalam Penanganan Covid-19 Menurut Undang-

Undang No. 2 Tahun 2020.” Jurnal Pakuan Law Review 6, no. 2 (2020):

24-41. https://doi.org/10.33751/palar.v6i2.2128.

Goodreads. "Cicero Quotes." Goodreads.com, n.d.

https://www.goodreads.com/quotes/531811-salus-populi-suprema-est-

lex-the-good-of-the-people.

Ichwanudin, Wawan. "Absennya Politik Pengawasan DPR Era Reformasi."

Jurnal Penelitian Politik 9, no. 2 (2010): 91-104. https://doi.org/https://doi.org/10.14203/jpp.v9i2.233.

Katadata. "Jokowi Teken Perpres Revisi Kedua APBN 2020, Deficit Angaran RP $1039 \quad$ T.” $\quad$ Katadata.co.id, n.d. https://katadata.co.id/agustiyanti/finansial/5ef592357d095/jokowiteken-pepres-revisi-kedua-apbn-2020-defisit-anggaran-rp1039-t.

Kontan. "Mengawal Perppu Covid-19." Kontan. co.id, n.d. https://analisis.kontan.co.id/news/mengawal-perppu-covid-19.

Merdeka. "Pemerintah Jokowi Resmi Ajukan Perubahan Susunan Anggaran Di APBN 2020 Ke DPR.” Merdeka.com, n.d. https://www.merdeka.com/uang/pemerintah-jokowi-resmi-ajukanperubahan-susunan-anggaran-di-apbn-2020-ke-dpr.html.

Mulyadi. Pemeriksaan Dalam Pengawasan. Bandung: Remaja Rosdakarya, 1984.

Negara, Lembaga Adiministrasi. Modul Pendidikan Dan Pelatihan Kepemimpinan Tingkat IV, Sistem Administrasi Negara Republik Indonesia (SANRI). Jakarta: Lan RI, 2008. 
Panjaitan, Saut P. "Jaminan Perlindungan Konstitusional Hak Tiap Orang Untuk Memperoleh Informasi Dan Berkomunikasi." Jurnal Simbur Cahaya 15, no. 42 (2010): 1957-58.

Pramukti, Angger Sigit, and Meylani Chayaningsih. Pengawasan Hukum Terhadap Aparatur Negara. Yogyakarta: Pustaka Yustisia, 2016.

Republika. "APD Yang Terus Menerus Kurang." Republika. co.id, n.d. https://republika.co.id/berita/q83350328/apd-yang-terus-meneruskurang.

Situmorang, M., Viktor, and Jusuf Juhir. Aspek Hukum Pengawasan Melekat Dalam Lingkungan Aparatur Pemerintah. Jakarta: Rineka Cipta, 1994.

Suadi, Amran. Sistem Pengawasan Badan Peradilan Di Indonesia. Depok: Rajawali Press, 2014.

WHO. "WHO Timeline - COVID-19." Who.int. Accessed April 27, 2020. https://www.who.int/news-room/detail/27-04-2020-who-timeline--covid-19. 